\title{
Biological investigations on the freshwater snail Pirenella conica (Blainville, 1829) infected with the developmental stages of Heterophyes sp.
}

\author{
El-Sayed T. Rizk ${ }^{1 *}$, Shadia F. Hamada², Sherif R. Abd-ElGhany² and Amany M. Ramez²
}

\begin{abstract}
Background: Heterophyiasis is an intestinal sickness promoted by infection with the heterophyid digenetic worms. It is one of the major infectious diseases of public health in the developing countries.

Method: Single-cell gel eletrophoresis, or comet assay, was carried out for detecting DNA damage in the digestive gland cells of Pirenella conica infected with Heterophyes larvae. Besides, apoptosis, some isoenzymes, and two biogenic amines (neurotransmitters) were investigated using the flow cytometric analysis, the starch gel electrophoresis, and the HPLC techniques respectively. Snails were collected from brackish water area around Port Said province during the spring-summer periods of 2012-2013.

Results: The results showed that infection with the larval trematodes increased tail length (length of DNA migration) in the digestive gland cells of infected snails. Meanwhile, the percentage of apoptosis was significantly elevated (58.80\%) in the snails infected with the larval trematodes as compared to that of uninfected snails (39. 59\%). Apparent polymorphism was detected in the four enzymes obtained from the digestive gland extracts.

Conclusion: DNA damage and increase of apoptosis in the digestive glands of infected snails may end up with a decrease of 5-HT (serotonin) and DA (dopamine) concentrations in all tissues through the course of infection.
\end{abstract}

Keywords: Comet assay, Isoenzymes, Neurotransmitters, Pirenella conica

\section{Background}

Heterophyiasis is an intestinal illness initiated by infection with the heterophyid digenetic flukes. It is one of the main infectious diseases of public health and socioeconomic position in the developing world (Pica, Castellano, Cilia, \& Errico, 2003; Massoud, El-Shazly, \& Morsy, 2007 and Youssef \& Uga, 2014). The freshwater mollusk Pirenella conica represents the intermediate hosts for many species of trematodes, including representatives of the heterophiidae family-Heterophyes. Freshwater snails are not inert hosts for trematodes, as they have an interior system that can identify, control, and remove pathogens (Ataev \& Coustau, 1999; Coustau, Gourbal, Mitta, \& Adema, 2009). A better

\footnotetext{
* Correspondence: rizktaha@yahoo.com

'Zoology Department, Faculty of Science, Tanta University, Tanta, Egypt Full list of author information is available at the end of the article
}

understanding of the physiology of vector snails may offer an effective tool in biological control (Abou-ElNaga \& Radwan, 2012). The interior defense system is a reason that influences the vulnerability form of the snails. Of all the aspects of snail biology affected by parasitic infection, reproductive success has undoubtedly been of great importance within the field. The biogenic monoamines is one class of molecules that characterizes a probable object for parasitic castration. These molecules show a wide variety of controlling functions in mollusks affecting on almost all physiological systems, comprising reproduction. Serotonin (5-hydroxytryptamine or 5-HT) and dopamine (DA) are amongst the furthermost extensively investigated monoamines (Bai, Johnston, Watson, \& Yoshino, 1997; Manger, Li, Christensen, \& Yoshino, 1996; Boyle \& Yoshino, 2002). Apoptosis is vital for the performance of the immune 
system of mollusks as shown by the apoptosis image detected in circulating digestive gland cells in infected cluster. Accordingly, the antiapoptotic factors show a part in host protection against parasites by restraining the pathogen feast while preventing inflammatory cell injury. Barcinski and DosReis (1999) revealed that control of host cell apoptosis is a serious factor in hostparasite interactions. Unfortunately, studies using the single-cell gel electrophoresis (the comet assay) to measure the special influences of parasitic infection on the DNA damage are relatively lacking. Starch gel electrophoresis of isozymes is a well-recognized technique for detecting genetic polymorphism (Tanksley \& Orton, 1983; Soltis \& Soltis, 1989; Wang, 1994).

\section{Methods}

\section{Collection and maintenance of snails}

A total of 1250 freshwater Pirenella conica snails, the intermediate host of Heterophyes spp., were collected from brackish water area around Port Said province using a hand wire mesh scoop (Araschewski, 1985 and Abou El-Azm, 1991) during spring-summer periods of 2012-2013. They were brought to the laboratory and maintained in separate aquaria containing freshwater and aquatic plants. The snails were successively examined for natural trematode infection by exposure to artificial light at $28{ }^{\circ} \mathrm{C}$ for cercarial shedding. Shells of the snails were removed, and the soft tissues were separated into the cephalopedal mass and digestive gland. The fresh tissues were weighed, divided into two groups, and maintained at $-10{ }^{\circ} \mathrm{C}$ until use.

\section{Flow cytometric analysis}

\section{Preparation and staining of cells}

Digestive gland sample was washed through the gauze with Tris/EDTA buffer (pH 7.5) [3.029 $\mathrm{g}$ of $0.1 \mathrm{M}$ Tris-(hydroxymethyl-aminomethane), $1.022 \mathrm{~g}$ of $0.07 \mathrm{M}$ sodium chloride, and $0.47 \mathrm{~g}$ of $0.005 \mathrm{M}$ EDTA]. They were dissolved in $250 \mathrm{ml}$ of distilled water, and then, the $\mathrm{pH}$ was adjusted at 7.5 by using $1 \mathrm{~N} \mathrm{HCl}$. The cell suspension was centrifuged at $108.67 \mathrm{~g}$ for $10 \mathrm{~min}$ whereupon the suspension was aspirated. After centrifugation and aspiration of the supernatant, the cell was fixed in ice-cold $96-100 \%$ ethanol approximately $1 \mathrm{ml}$ for each sample. The fixed cells can be stored indefinitely in a refrigerator and can also be mailed without running the sample. Preparation of propidium iodide stain, $0.1 \mathrm{~g}$ sodium citrate, $0.1 \mathrm{ml}$ Triton X-100, and $5 \mathrm{mg}$ propidium iodide were dissolved in $100 \mathrm{ml}$ distilled water. The cells were stained according to Nicoletti et al. (2001). Briefly, the tubes containing digestive gland cells were centrifuged at $105.67 \mathrm{~g}$ for $10 \mathrm{~min}$ and the supernatant was discarded. The sample was washed with $2 \mathrm{ml}$ phosphate-buffered solution (PBS) and again centrifuged at $105.67 \mathrm{~g}$ for $5 \mathrm{~min}$, and the supernatant was discarded. The cells were re-suspended with PBS, and 200-500 $\mu \mathrm{l}$ was taken from the sample into the polystyrene tube. $1.5 \mathrm{ml}$ of propidium iodide staining solution was added, and the tube was incubated for $1 \mathrm{~h}$ at $4{ }^{\circ} \mathrm{C}$ in dark place until acquisition. Then, the sample was run in the flow cytometer within overnight after the addition of propidium iodide to analyze the sub- $\mathrm{G}_{1}$ of apoptosis.

The flow cytometry used at Mansoura University Hospital for children is FACSCalibar flow cytometer (Becton Dickinson, Sunnyvale, CA, USA) equipped with a compact air-cooled low-power $15 \mathrm{~mW}$ Argon-ion laser beam $(488 \mathrm{~nm})$. The average number of evaluated nuclei per specimen was 20,000 , and the number of nuclei scanned was 120 per second. DNA histogram derived from flow cytometry was obtained with a computer program for Dean and Jett mathematical analysis (Dean \& Jett, 1974). Data analysis was conducted using DNA analysis program MODFIT (verity software house, Inc., version: 2.0 power Mac with 131,072 KB registration no. 42000960827-16193213). This software calculated the $\mathrm{CV}$ around the $\mathrm{G}_{0} / \mathrm{G}_{1}$ peak and the percentage of cells in each phase $\left(G_{0} / G_{1}, S\right.$, and $\left.G_{2} / M\right)$ of the DNA cell cycle for each sample.

Apoptosis was measured by using the sub- $\mathrm{G}_{1}$ peak staining with iodide (Cohen and Al-Rubeai, 1995). An aneuploid cell population was considered to be present if a distinct peak, in addition to the $\mathrm{G}_{1}$ dipliod peak, was found in position deviating more than $10 \%$ from the dipliod.

\section{The single-cell gel electrophoresis (comet assay)}

The removed digestive glands were prepared according to the technique used by Sasaki, Nishidate, Izumiyama, Matsusaka, and Tsuda (1997).

\section{Starch gel electrophoresis for isozymes}

The investigated tissues were macerated in their specific extraction solution. The extract was then filtered. The electrophoresis was performed in approximately $4 \mathrm{~h}$; during this time, the front migrated 8 to $8.5 \mathrm{~cm}$ from the origin. The staining reaction was usually stopped by rinsing the gels with tap water several times. Gels were then fixed in $50 \%$ glycerol overnight, wrapped in plastic film, and stored in the refrigerator until photographed, or dried and stored afterwards.

\section{Determination of the tested monoamines}

The dissected frozen soft parts were put in the Eppendorf tubes and weighed. Then, each tissue was homogenized with an ultrasonic cell disrupter in $150 \mu \mathrm{l} 0.1 \mathrm{M}$ perchloric acid inclosing $0.4 \mathrm{mM}$ sodium metabisulfite. The homogenates were later centrifuged at $10,000 \mathrm{~g}$ for $25 \mathrm{~min}$ at $4{ }^{\circ} \mathrm{C}$, and the supernatants were filtered via a 
Table 1 Digestive gland $\mathrm{P} 53 \%, \mathrm{BCl} 2 \%$, and apoptosis \% (sub-G $\mathrm{G}_{1}$ ) in uninfected (control) and infected snails

\begin{tabular}{lllll}
\hline Flow & Groups & Uninfected (control) & Infected & ANOVA \\
\hline Mean \pm SE & P53\% & $39.82 \pm 1.4$ & $74.49 \pm 3$ & $P \leq 0.05$ \\
Mean \pm SE & BCl $_{2} \%$ & $65.35 \pm 2.6$ & $39.31 \pm 2.4$ & \\
Mean \pm SE & Apoptosis \% & $39.59 \pm 1.5$ & $58.80 \pm 2.1$ & \\
\hline
\end{tabular}

$0.2-\mu \mathrm{m}$ filter and frozen at $-70{ }^{\circ} \mathrm{C}$ until analysis. After that, $5 \mu \mathrm{l}$ of filtrates was injected into the HPLC system. The mobile phase contained $0.15 \mathrm{M}$ sodium dihydrogen phosphate, $0.1 \mathrm{mM}$ EDTA, $0.5 \mathrm{mM}$ sodium octanesulfonic acid, $10-12 \%$ methanol $(v / v)$, and $5 \mathrm{mM}$ lithium chloride. The mobile phase was accustomed to $\mathrm{pH} 3.4$ with phosphoric acid, filtered over $0.22-\mu \mathrm{m}$ filter, and

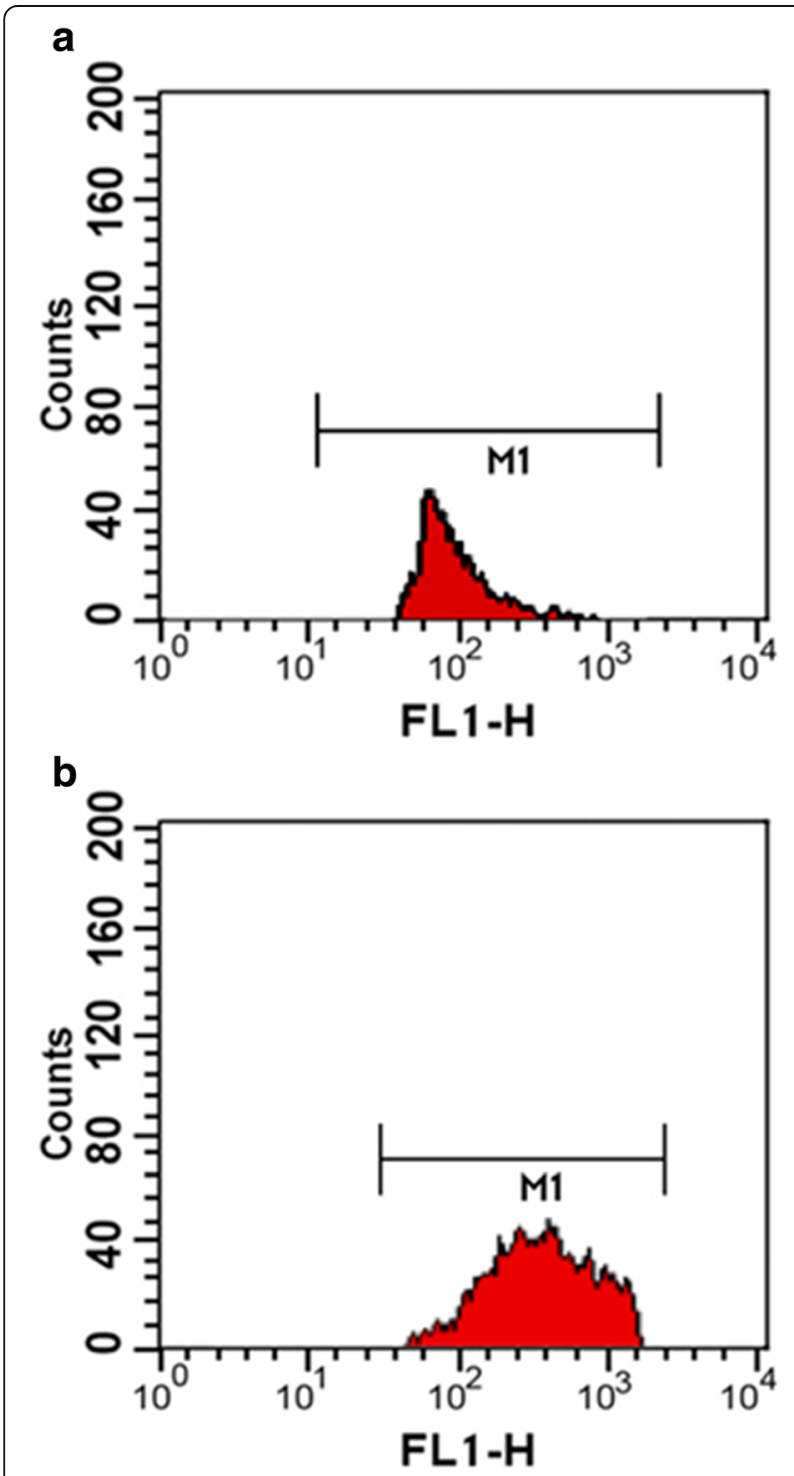

Fig. 1 Digestive gland P53\% in uninfected (a) and infected (b) snails. M1, percent of gated cells stained with + ve $P^{53}$ degassed with helium. A column temperature of $32{ }^{\circ} \mathrm{C}$ and a flow rate of $1.4 \mathrm{ml} / \mathrm{min}$ were used.

\section{Statistical analysis}

The results obtained in the current study were assessed by one-way ANOVA test, and post comparison was supported by a Duncan test. The data were stated as means \pm standard error $(X \pm \mathrm{SE})$. The values of $p \leq 0.05$ were reflected statistically significant (Snedecor \& Cochran, 1982).

\section{Results}

Flow cytometric analysis of cell cycle

Table 1 and Figs. 1, 2, and 3 illustrated digestive gland $\mathrm{P} 53 \%, \mathrm{BCl} 2 \%$, and apoptosis $\%$ (sub- $\mathrm{G}_{1}$ ) in uninfected and infected snails. Results illustrated that the levels of apoptosis \% were significantly elevated (58.80\%) in the snails infested with the trematode larvae as compared to that of uninfected snails (39.59\%). On the other hand, the data indicated pronounced elevation in the $\mathrm{P} 53 \%$ (74.49\%) and decrease in the $\mathrm{BCl} 2 \%$ (39.31\%) in the infected snails compared with those of the control (uninfected) snails which were $39.82 \%$ and $65.35 \%$ respectively.

\section{The single-cell gel electrophoresis (comet assay)}

From Table 2 and Fig. $4(1,2)$, infection with the larval trematodes increased tail length (length of DNA migration) in the digestive gland cells which exhibited numerical increase of apoptotic cell death.

\section{Starch gel electrophoresis for isozymes}

Using the starch gel electrophoresis, characteristic isozyme fingerprints of four enzymes were obtained from the digestive gland extracts of uninfected and infected Pirenella snails, and a number of differentially expressed fragments of the digestive gland were identified. All bands migrated anodally. They were labeled in descending order toward the cathode. Apparent polymorphism was detected in the four enzymes used (Fig. 5).

Isoenzymes in acid phosphatase (Ac Ph) have great possibilities of not being significantly different from one another. Three isozymes of glucose-6-phosphatase (G-6ph) were recognized with difference in the third band. Differences between alkaline phosphatase (Alk Ph) and lactate dehydrogenase (LDH) isozymes could be found with a loss of the first and the fourth isoenzymes, respectively.

Differential expression was verified using UPGMA analysis, which was shown to be a valuable method for this purpose. The dendrogram calculated the similarity between the tested isozymes. The results indicated a similarity of $77.78,70.00,58.82$, and $80.00 \%$ between the isozymes of G-6-Ph, Ac $\mathrm{Ph}$, Alk $\mathrm{Ph}$, and $\mathrm{LDH}$, respectively (Fig. 6). 


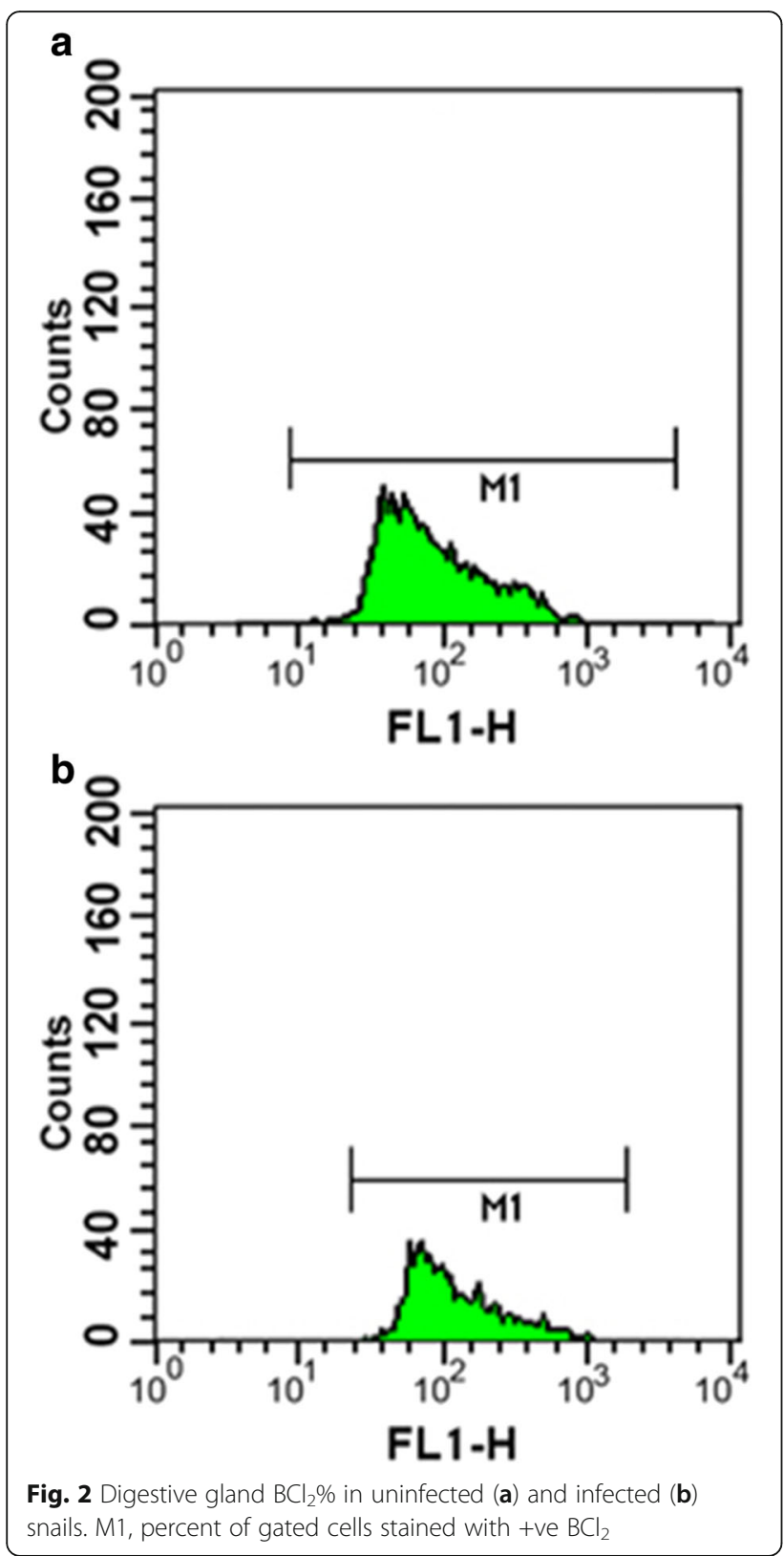

\section{Determination of the tested monoamines}

Two biogenic amines, dopamine (3,4-dihydroxytyramine or DA) and serotonin (5-hydroxytryptamine or 5-HT), were recognized and measured by HPLC in homogenates of snails' soft parts. Chromatograms from HPLC analysis of separate tissue samples were reliable in displaying peaks for these two biogenic amines (Fig. 7). They were recognized by their coalition with reliable amine standards and evaluations of retaining times in standard buffer and electrode potential circumstances.

The levels of DA in the soft parts were comparable between Heterophyes infected and uninfected $P$. conica (Table 3). Significant decreases in dopamine relative to control were detected.

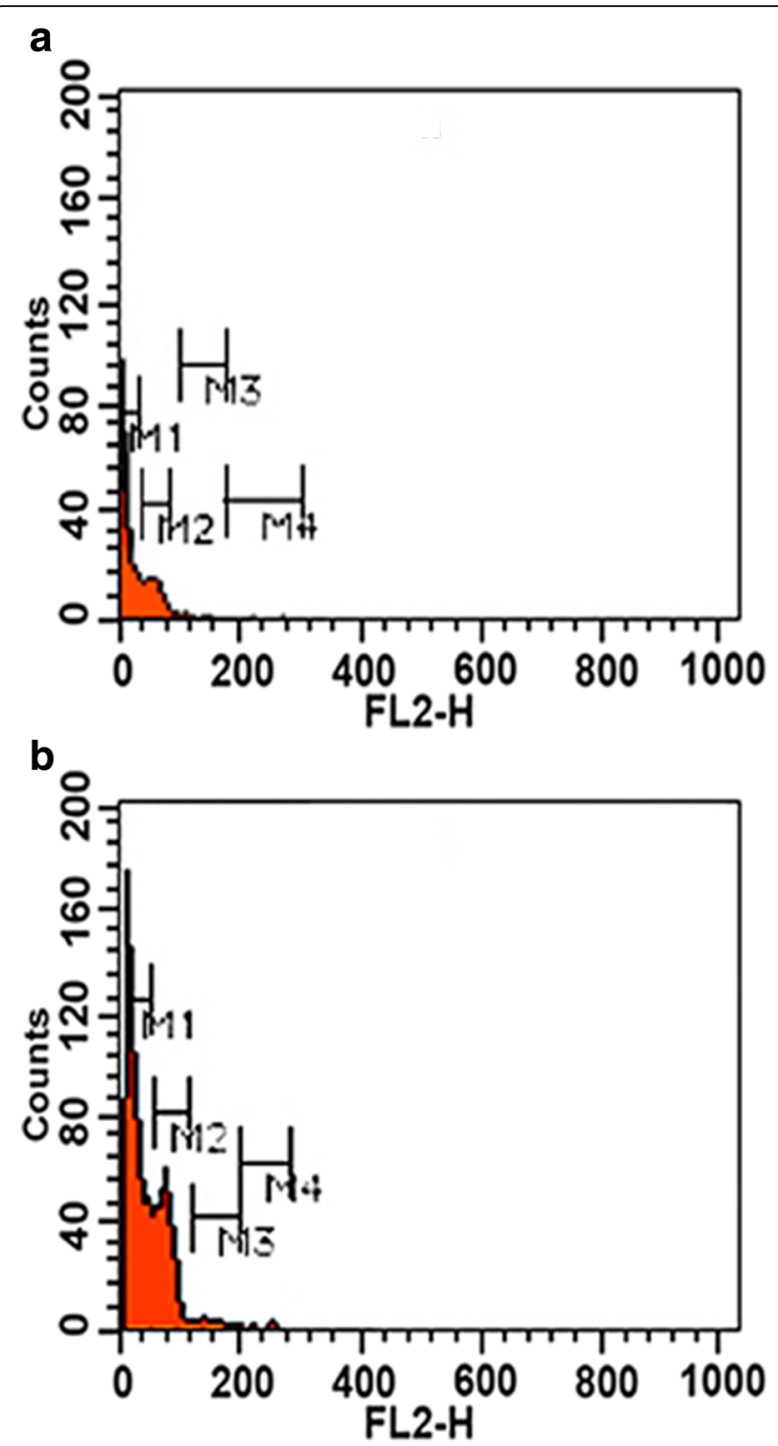

Fig. 3 Digestive gland apoptosis \% (sub G1) in uninfected (a) and infected (b) snails. M1, percent of apoptosis

The overall effect of infection was a decrease of 5-HT content in all tissues through the infection course.

\section{Discussion}

The obtained results showed that the overall number of apoptotic cells in infested snails was significantly increased than that of control ones. This result may be

Table 2 Comet assay of apoptotic digestive gland of both uninfected control (C) and infected (I) snails

\begin{tabular}{|c|c|c|c|c|c|c|c|c|c|c|}
\hline \multirow[t]{2}{*}{ Group } & \multicolumn{2}{|c|}{ \% Tailed } & \multicolumn{2}{|c|}{$\%$ Untailed } & \multicolumn{2}{|c|}{$\begin{array}{l}\text { Tail length } \\
(\mu \mathrm{m})\end{array}$} & \multicolumn{2}{|c|}{$\begin{array}{l}\text { \% Tail } \\
\text { DNA }\end{array}$} & \multicolumn{2}{|c|}{$\begin{array}{l}\text { Tail moment } \\
\text { (unit) }\end{array}$} \\
\hline & $\mathrm{C}$ & 1 & $\mathrm{C}$ & 1 & $\mathrm{C}$ & 1 & $\mathrm{C}$ & 1 & $\mathrm{C}$ & 1 \\
\hline Mean & 5 & 17 & 95 & 83 & 1.49 & 3.56 & 1.59 & 3.20 & 2.368 & 11.298 \\
\hline$\pm \mathrm{SE}$ & 0.3 & 0.5 & 0.3 & 0.5 & 0.07 & 0.37 & 0.06 & 0.07 & 0.04 & 0.3 \\
\hline
\end{tabular}



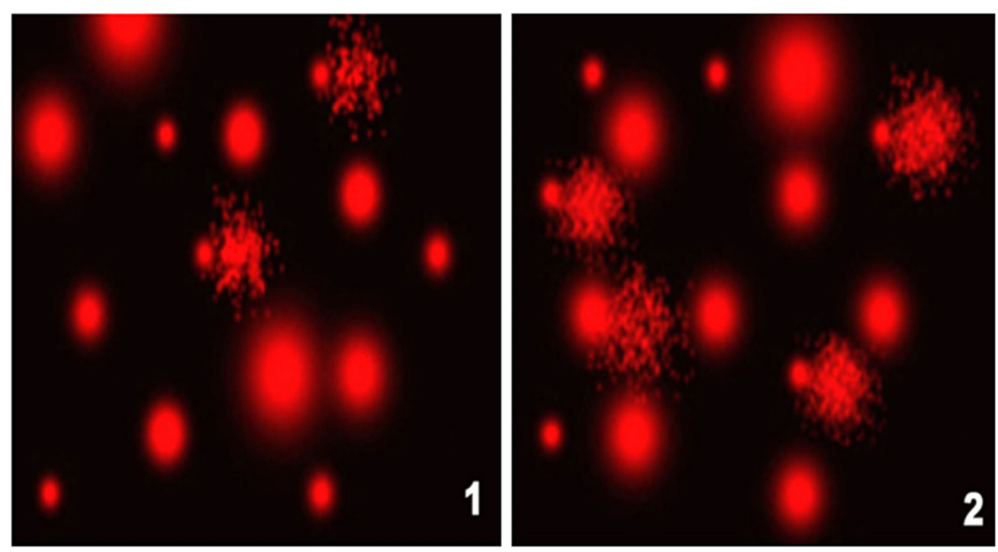

Fig. 4 Comet assay of the digestive gland cells of the uninfected (1) and infested snails (2). Note DNA migration and increased stretching apoptotic cells in infected individuals

due to the decline in lysosomal stability initiated by reactive oxygen species (ROS). Under conditions affecting oxidative stress, the lysosomal membrane may well rupture leading to the discharge of enzymes into the cytoplasm (Cheng, 1983; Öllinger \& Brunk, 1995; Zdolsek, Olson, \& Brunk, 1990; Winston, Moore, Kirchin, \& Soverchia, 1996; Zhao, Antunes, Eaton, \& Brunk, 2000). Thus, lysosomes have been assumed as being responsible for the death of cells: the leak of lytic enzymes into the cytosol might cause degenerative changes and initiate cell death. Apoptotic processes are characterized by many morphological features, which have been stated by Sweet, Passino-Reader, Meier, and Omann (1999). Furthermore, Romero, Estévez-Calvar, Dios, Figueras, and Novoa (2011) stated that the adequate clearance of damaged, senescent, and infested cells without inflammation are supported by apoptosis. It is well known that the molluscan immune system is based on innate mechanisms, whereas humoral and cellular processes approve cytotoxic and antimicrobial roles (Auffret, Rousseau, Boutet, Tanguy, \& Baron, 2006).

Outcomes of the present study is in agreement with former studies of biogenic amines in freshwater gastropods (for example, Hetherington, McKenzie, Dean, \& Winlow, 1994; Ottaviani, Caselgrandi, Petraglia, \& Franceschi, 1992). Chiang, Bourgeois, and Beuding (1974) separated and identified dopamine and 5-HT in numerous tissues of Balanus glabrata, plus the ganglia, cephalopedal area, and mantle. To evaluate the role of bioamines in controlling molluscan reproductive activity, the effect of trematode larvae infection on reproduction of host and bioamine concentration was of real interest. Infection of parasite could cause major depressions, as compared to matched controls, of biogenic monoamine contents in the soft parts. Parasitic induction for depressed DA and 5-HT levels can be supported by several mechanisms. A large population of parasites mount

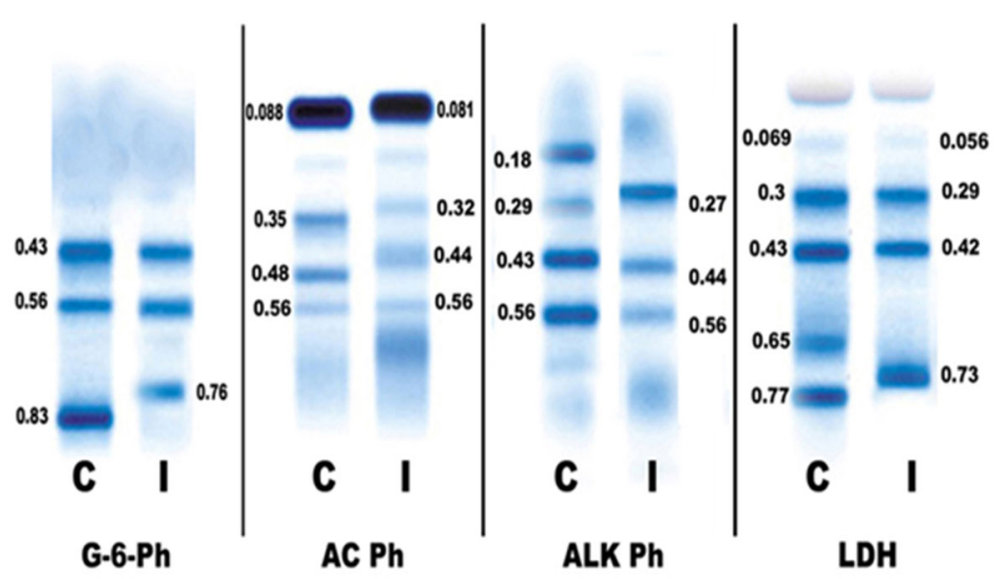

Fig. 5 Mean gels showing positions of bands electrophoresed on both uninfected control (C) and infected (I) groups stained for G-6-Ph, Ac Ph, Alk $\mathrm{Ph}$, and LDH 


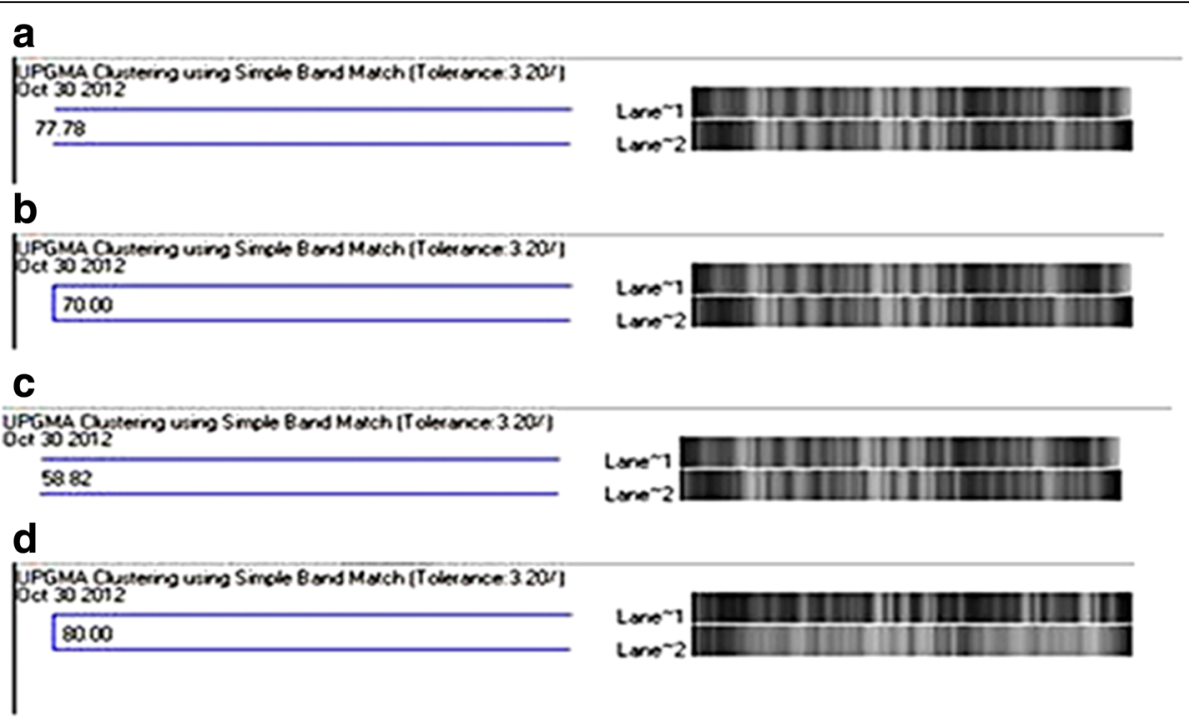

Fig. 6 a-d Similarity dendrogram resulting from analysis of isozymes bands of both uninfected and infected groups

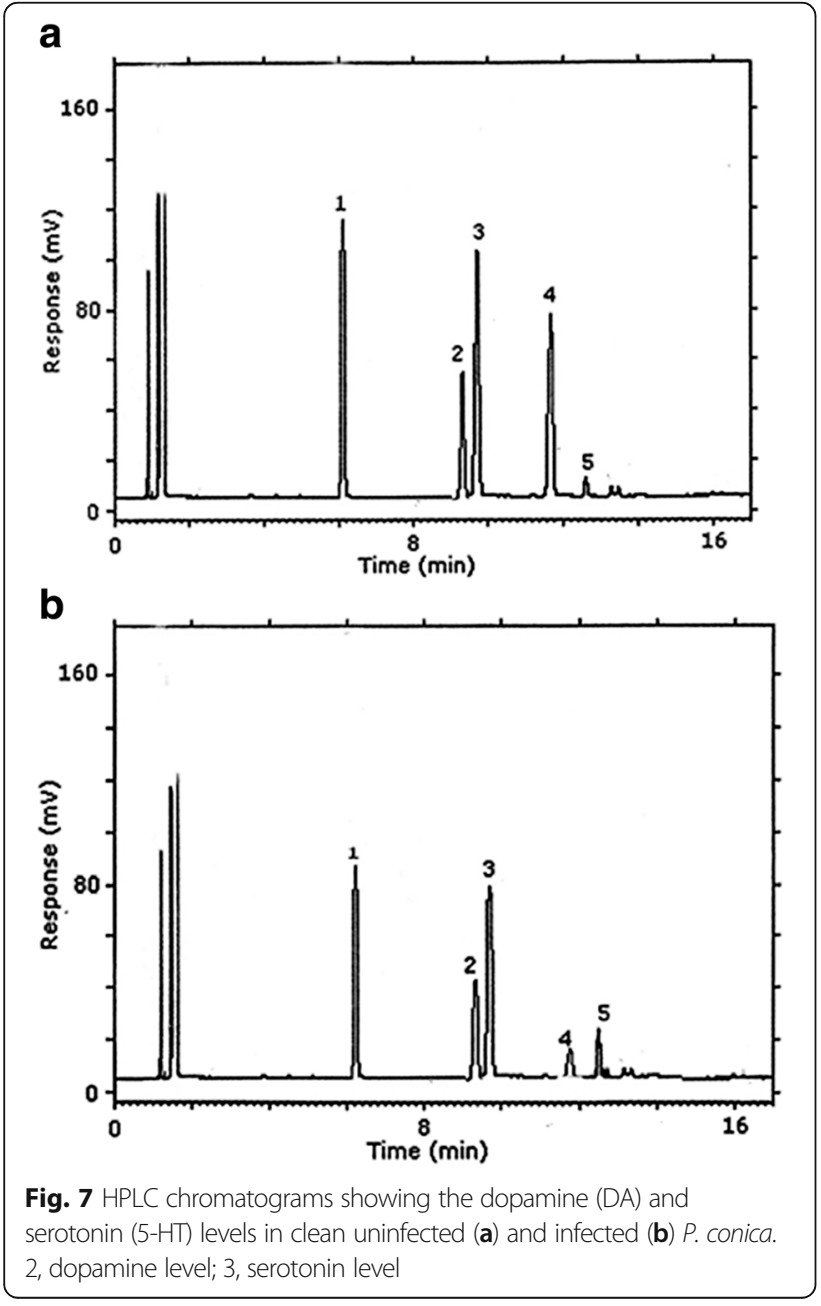

up in the snail after a fairly short period time of the asexual reproduction of the parasite. So, a progressive decrease of neurotransmitters in the plasma and later in infection and in amine-producing tissues may be expected. Then, an extensive physical or pathophysiological disorder of the snails' aminergic system or secretion by parasite-derived molecules or specific interference of host bioamine production can be caused by parasites. On the other hand, Chiang et al. (1974) indicated that they were unable to identify any effects of infection of schistosome larvae on snail biogenic amine contents, although no records were offered to support this statement. This identified difference may reflect the relative sensitivities of the applied techniques, though other explanations including variances in sample analysis, age of the host at the time of infection, preliminary infection dose, and the accurate timing of castration might have been causative factors.

In summary, a prominent class of biomolecules that role in many physiological processes of mollusks, including reproduction, is characterized by biogenic monoamines. Hence, these molecules represent a probable objective for parasite manipulation of host reproductive activity. The present investigation verifies a damage of 5-HT and dopamine in the tissues of Pirenella through

Table 3 Effect of Heterophyes larvae infection on dopamine (DA) and serotonin (5-HT) in clean uninfected (C) and infected (I) P. conica

\begin{tabular}{llllll}
\hline Group & DA & & & $5-H T$ & \\
\cline { 2 - 3 } \cline { 6 - 7 } & C & I & & C & I \\
\hline Mean & 55.68 & 42.45 & & 105.06 & 81.51 \\
\pm SE & 0.7 & 0.7 & & 0.7 & 0.8 \\
\hline
\end{tabular}


infection by Heterophyes larvae that is linked with the start of parasitic castration. As endogenous serotonin is inhibited in Pirenella via infection by trematode, it has a stimulatory effect on reproductive processes in these snails. Finally, parasitic castration may be intermediated in the snail by the parasitic manipulation of host serotonin concentrations.

The performed study has revealed that invasion with cercariae of trematodes Heterophyes lead to the statistically significant increase of DNA fragmentation and migration in the molluscan tissues as compared with control. This was in agreement with Mohamed (2011) who found that flow cytometric analysis of cell cycle and comet assay caused DNA damage in Biomphalaria alexandrina hemocytes exposed to Schistosoma mansoni infection when compared to control group.

There is an unlucky inclination in the study of Johnson (1973) to propose that multiple electrophoretic bands establish straight indication of heterozygosity at a protein locus. Breeding investigates identical to those carried out by Oxford (1973) and Brussard and McCracken (1974) are best confirmed by genetic relationships. Several cases of isoenzyme variation were documented to be due to molecular instability (Beardmore, 1970).

There are still many aspects to be investigated in host-trematode interactions. To our knowledge, this is the first description of the changes and modification of metabolic interactions in the Pirenella-Heterophyes model.

\section{Conclusions}

In conclusion, DNA damage and increase of apoptosis in the digestive glands of infected snails may end up with a decrease of 5-HT (serotonin) and DA (dopamine) concentrations in all tissues through the course of infection.

\section{Acknowledgements}

Not applicable.

\section{Funding}

Not applicable.

\section{Availability of data and materials}

The datasets generated and analyzed during the current study is available from the corresponding author on a reasonable request.

\section{Authors' contributions}

ESR wrote the manuscript, contributed to the design of the study, and carried out the data analysis. SH coordinated the design of the study and was responsible for the execution of the experiment. SAE helped to write the manuscript. FAR contributed to the design of the study, contributed to the literature review, and critically revised the manuscript. Finally, AR provided the idea for the study, coordinated the study, and critically revised the manuscript. All authors read and approved the final manuscript.

\section{Ethics approval and consent to participate}

The authors were asked to participate in a satisfaction survey on a voluntary basis. Participants were informed that this survey was part of a research project. This study was approved by the Social Science Ethical Committee of Faculty of Science, Tanta University and Research, and complied with the Egyptian Code of Conduct for Scientific Practice, National institute of research, Egypt.

\section{Consent for publication}

Not applicable.

\section{Competing interests}

The authors declare that they have no competing interests.

\section{Publisher's Note}

Springer Nature remains neutral with regard to jurisdictional claims in published maps and institutional affiliations.

\section{Author details}

${ }^{1}$ Zoology Department, Faculty of Science, Tanta University, Tanta, Egypt. ${ }^{2}$ Zoology Department, Faculty of Science, Mansoura University, Mansoura, Egypt.

Received: 18 May 2017 Accepted: 5 January 2018

Published online: 22 January 2018

\section{References}

Abou El-Azm, F.A. (1991). Molluscicide gene resistance and effects of carboxylic acids on the snail vectors of schistosomiasis, PhD thesis. Tanta: Tanta University cited from Abou El-Azm 1991.

Abou-El-Naga, I. F., \& Radwan, E. H. (2012). Defense response of susceptible and resistant Biomphalaria alexandrina snails against Schistosoma mansoni infection. Revista de Biología Tropical, 60(3), 195-204.

Araschewski, H. (1985). Investigations on the prevalence of Heterophyes species in twelve populations of the first intermediate host in Egypt and Sudan. The Journal of Tropical Medicine and Hygiene, 88(4), 265-271.

Ataev, G., \& Coustau, C. (1999). Cellular response to Echinostoma caproni infection in Biomphalaria glabrata strains selected for susceptibility/resistance. Developmental and Comparative Immunology, 23, 187-198.

Auffret, M., Rousseau, S., Boutet, I., Tanguy, A., \& Baron, J. (2006). A multiparametric approach for monitoring immunotoxic responses in mussels from contaminated sites in Western Mediterranea. Ecotoxicology and Environmental Safety, 63, 393-405.

Bai, G., Johnston, L. A., Watson, C. O., \& Yoshino, T. P. (1997). Phenoloxidase activity in the reproductive system of Biomphalaria glabrata: Role in egg production and effect of schistosome infection. The Journal of Parasitology, 83, 852-858.

Barcinski, M. A., \& DosReis, G. A. (1999). Apoptosis in parasites and parasiteinduced apoptosis in the host immune system: A new approach to parasitic diseases. Brazilian Journal of Medical and Biological Research, 32, 395-401.

Beardmore, J. (1970). Ecological factors and the variability of gene-pools in Drosophila. In M. Hecht, \& W. Steere (Eds.), Essays in evolution and genetics in honor of Theodosius Dobzhansky, (p. 299). New York: Appleton.

Boyle, J. P., \& Yoshino, T. P. (2002). Monoamines in the albumen gland, plasma, and central nervous system of the snail Biomphalaria glabrata during egg-laying. Comparative Biochemistry and Physiology, 132, 411-422.

Brussard, P. F., \& McCracken, G. F. (1974). Allozyme variation in a North American colony of Cepaea nemoralis. Heredity, 33, 98.

Cheng, T. (1983). The role of lysosomes in molluscan inflammation. American Zoologist, 23, 129-144.

Chiang, P. K., Bourgeois, J. G., \& Beuding, E. (1974). 5-Hydroxytryptamine and dopamine in Biomphlaria glabrata. The Journal of parasitology, 60, 264-271.

Cohen, J. J., \& Mohamed, A. R. (1995). Apoptosis-targeted therapies: the 'next big thing' in biotechnology?. Trends in biotechnology, 13(8), 281-283.

Coustau, C., Gourbal, B., Mitta, G., \& Adema, C. (2009). Echinostomes and snails: Exploring complex interactions. In B. Fried, \& R. Toledo (Eds.), The biology of echinostomes: From the molecule to the community, (pp. 35-59). New York: Springer.

Dean, P. N., \& Jett, J. H. (1974). Mathematical analysis of DNA distributions derived from flow microfluorometry. The Journal of Cell Biology, 60, 523-527. 
Hetherington, M. S., McKenzie, J. D., Dean, H. G., \& Winlow, W. (1994). A quantitative analysis of the biogenic amines in the central ganglia of the pond snail, Lymnaea stagnalis (L.) Comparative Biochemistry and Physiology, 107C, 83-93.

Johnson, G. B. (1973). Enzyme polymorphism and biosystematics; the hypothesis of selective neutrality. Annual Review of Ecology and Systematics, 4, 93.

Nicoletti, I., Mannuci, R., Migloirati, G., Riccardi, C., \& Grignani, F. (2001). Common method for measuring apoptotic cell death by flow cytometry. Purdue Cytometry CD-ROM Series, 3, 1-9.

Manger, P., Li, J., Christensen, B. M., \& Yoshino, T. P. (1996). Biogenic monoamines in the freshwater snail, Biomphalaria glabrata: Influence of infection by the human blood fluke, Schistosoma munsoni. Comparative Biochemistry and Physiology, 114A(3), 227-234.

Massoud, A. M., El-Shazly, A. M., \& Morsy, T. A. (2007). Mirazid (commiphora molmol) in treatment of human heterophyiasis. Journal of the Egyptian Society of Parasitology, 37, 395-410.

Mohamed, A. Z. (2011). Sublethal toxicity of roundup to immunological and molecular aspects of Biomphalaria alexandrina to Schistosoma mansoni infection. Ecotoxicology and Environmental Safety, 74(4), 754-760.

Öllinger, K., \& Brunk, U. T. (1995). Cellular injury induced by oxidative stress is mediated through lysosomal damage. Free Radical Biology \& Medicine, 19, $565-574$.

Ottaviani, E., Caselgrandi, E., Petraglia, F., \& Franceschi, C. (1992). Stress response in the freshwater snail Planobarius curnius (L.) (Gastropoda, Pulmonata): Interaction between CRF, ACTH, and biogenie amines. General and Comparative Endocrinology, 87, 354-360.

Oxford, G. S. (1973). The genetics of Cepaea esterases. Heredity, 30, 127.

Pica, R., Castellano, C., Cilia, C., \& Errico, F. O. (2003). Intestinal fluke infections: The heterophyids. La Clinica Terapeutica, 154, 61-63.

Romero, A., Estévez-Calvar, N., Dios, S., Figueras, A., \& Novoa, B. (2011). New insights into the apoptotic process in mollusks: Characterization of caspase genes in Mytilus galloprovincialis. PLoS One, 6(2), e17003. https://doi.org/10. 1371/journal.pone.0017003.

Sasaki, Y. F., Nishidate, E., Izumiyama, F., Matsusaka, N., \& Tsuda, S. (1997). Simple detection of chemical mutagens by the alkaline single-cell gel electrophoresis (comet) assay in multiple mouse organs. Mutation Research, 391, 215-231

Snedecor, G. W., \& Cochran, W. G. (1982). Statistical methods, (7th ed., p. 593). American, lowa: The State University Press.

Soltis, D. E., \& Soltis, P. M. (1989). Isozymes in plant biology, (p. 268). Oregon: Diosc. Press.

Sweet, L., Passino-Reader, D., Meier, P., \& Omann, G. (1999). Xenobiotic induced apoptosis: Significance and potential application as a general biomarker of response. Biomarkers, 4, 237-253.

Tanksley, S. D., \& Orton, T. J. (1983). Isozymes in plant genetics and breeding. Amsterdam: Elsevier part A, p.516, Part B, p. 472

Wang, X. (1994). Analysis of electrophoretic patterns of three enzymes of Oncomelania hupensis. Chinese Journal of Parasitology \& Parasitic Diseases, 12(4), 271.

Winston, G. W., Moore, M. N., Kirchin, M. A., \& Soverchia, C. (1996). Production of reactive oxygen species by hemocytes from the marine mussel, Mytilus edulis: Lysosomal localisation and effect of xenobiotics. Comparative Biochemistry and Physiology, 113, 221-229.

Youssef, A. I., \& Uga, S. (2014). Review of parasitic Zoonoses in Egypt. Tropical Medicine and Health, 42(1), 3-14.

Zdolsek, J. M., Olson, G. M., \& Brunk, U. T. (1990). Photooxidative damage to lysosomes of cultured macrophages by acridine orange. Photochemistry and Photobiology, 51, 67-76.

Zhao, M., Antunes, F., Eaton, J. W., \& Brunk, U. T. (2000). Lysosomal enzymes promote mitochondrial oxidant production, cytochrome $\mathrm{c}$ release and apoptosis. European Journal of Biochemistry, 270, 3778-3786.

\section{Submit your manuscript to a SpringerOpen ${ }^{\circ}$ journal and benefit from:}

- Convenient online submission

- Rigorous peer review

- Open access: articles freely available online

- High visibility within the field

- Retaining the copyright to your article

Submit your next manuscript at $\boldsymbol{\nabla}$ springeropen.com 